Ks. Grzegorz BABIARZ*

\title{
POZNANIE I WOLNA WOLA - DWIE PODSTAWOWE KATEGORIE ANTROPOLOGII AMBROZJASTRA
}

Dzięki pracy Erazma z Rotterdamu ze spuścizny teologiczno-homiletycznej Ambrożego została wyodrębniona grupa pism, przypisana z czasem anonimowej postaci, której nadano pseudonim Ambrozjaster. Do tej grupy zalicza się Komentarz do Listów św. Pawta oraz Quaestiones ${ }^{2}$. W ramach pierwszej grupy na uwagę zasługuje komentarz do listu do Rzymian, który dostępny jest w trzech wersjach redakcyjnych. Możliwość ich porównania może posłużyć do oceny warsztatu oraz zaangażowania w precyzowanie poglądów przez naszego autora oraz ich roli w przenoszeniu prawdy tekstu natchnionego w środowisko współczesnych mu chrześcijan półwyspu apenińskiego doby IV w. Przypuszcza się, że byli to ludzie z wyższych kręgów społecznych o szerokiej wiedzy filozoficznej.

Po stosunkowo długim okresie milczenia na temat spuścizny naszego autora, początek wieku XX przyniósł pierwsze analizy związane z ustaleniem jego tożsamości. Tego zadania podjęli się: Germain Morin ${ }^{3}$, Otto Scholz ${ }^{4}$, Willibald Schwierholtz ${ }^{5}$, Alexander Souter ${ }^{6}$, Henricus Vogels ${ }^{7}$. Ten ostatni podjął też prace edytorsko-redaktorskie przy wydawaniu tekstów komentarza. Drugi okres badań w dużej mierze zawdzięczamy środowisku patrologów polskich:

${ }^{*}$ Ks. dr Grzegorz Babiarz - absolwent patrologii w Instytucie Teologii Dogmatycznej na Wydziale Teologicznym Uniwersytetu Papieskiego Jana Pawła II w Krakowie; e-mail: babiarzgrzegorz@gmail.com.

${ }^{1}$ Por. Ambrosiastri qui dicitur commentarius in epistulas Paulinas in epistulam ad Romanos, ed. H.I. Vogels, CSEL 81/1, Wien 1966; Ambrosiastri qui dicitur commentarius in epistulas Paulinas in epistulas ad Corinthios, ed. H.I. Vogels, CSEL 81/2, Wien 1968; Ambrosiastri qui dicitur commentarius in epistulas Paulinas in epistulas ad Galatas, ad Efesios, ad Filippenses, ad Colosenses, ad Thesalonicenses, ad Timotheum, ad Titum, ad Filemonem, ed. H.I. Vogels, CSEL 81/3, Wien 1969.

${ }^{2}$ Por. Quaestiones Veteris et Novi Testamenti CXXVII, ed. A. Souter, CSEL 50, Wien 1908.

${ }^{3}$ Por. G. Morin, Qui est l'Ambrosiaster? Solution nouvelle, RBen 31 (1914) 1-34.

${ }^{4}$ Por. O. Scholz, Die Hegesippus-Ambrosius-Frage. Eine literarhistorische Beschprechung, „Kirchengeschichtliche Abhandlungen” 8 (1909) 149-195.

${ }^{5}$ Por. W. Schwierholtz, Hilarii in epistola ad Romanos. Ein Beitrag zur Ambrosiasterfrage, „Kirchengeschichtliche Abhandlungen” 8 (1909) 57-96.

${ }^{6}$ Por. A. Souter, Studies of Abrosiaster, Cambridge 1905.

${ }^{7}$ Por. H. Vogels, Das Corpus Paulinum des Ambrosiaster, Bonn 1957. 
Marianowi Michalskiemu ${ }^{8}$, Emilowi Stanuli ${ }^{9}$ i Edwardowi Stańkowi ${ }^{10}$; w polu ich zainteresowania znalazły się: chrystologia, antropologia, angelologia, eklezjologia oraz wiara. Trzeci okres badań przypada na ostatnią dekadę, należy wymienić tu następujące nazwiska: Arkadiusz Baron ${ }^{11}$, Jan Żelazny ${ }^{12}$, Krzysztof Tyburowski ${ }^{13}$, Marie-Pierre Bussières ${ }^{14}$ oraz Sophie Lunn-Radckli$\mathrm{fe}^{15}$. Antropologia Ambrozjastra stała się przedmiotem badań Stanuli i Tyburowskiego. Obaj podkreślają, że analizy jakich dokonuje nasz autor często inspirowane sa jego osobistymi zainteresowaniami.

Ambrozjaster próbuje uzgodnić tradycję filozoficzną i teologiczną poruszając dwa zagadnienia: wartości ludzkiej natury oraz realizacji relacji wolitywnej i poznawczej przy poszanowaniu prawa Boga. Poglądy naszego autora zasługują na uwagę ze względu na zależności czasowe między nim i jego poprzednikiem, Mariuszem Wiktorynem, oraz następcami, Pelagiuszem i Augustynem, wzajemnymi oponentami, czerpiącymi z tekstów św. Pawła ${ }^{16}$. Na powyższe problemy postaram się odpowiedzieć posługując się metodą historyczno-porównawczą oraz w końcowej części pracy metodą historyczną. Analizy zostaną przedstawione w trzech punktach: elementy ludzkiej natury, racjonalność poznania i zakres wolnej woli.

\footnotetext{
${ }^{8}$ Por. M. Michalski, Problem tak zwanego „Ambrozjastra” w świetle jego nauki chrystologicznej, Kraków 1950.

${ }^{9}$ Por. E. Stanula, Aniołowie oraz ich upadek wedtug Ambrozjastra, STV 13 (1975) 105-116; tenże, Nauka Ambrozjastra o stanie pierwotnym człowieka. Studium z zakresu antropologii teologicznej, SACh 1 (1977) 3-120.

${ }^{10}$ Por. E. Staniek, Usprawiedliwiajacy charakter chrześcijańskiej wiary. Studium nad Komentarzami Ambrozjastra i Pelagiusza, Kraków 1982 (mps).

${ }^{11}$ Por. A. Baron, Lacińskie komentarze do Listu do Tytusa (Ambrozjaster, Hieronim, Pelagiusz) na tle recepcji myśli Pawłowej w starożytności. Studium porównawcze, w: Ambrozjaster - Hieronim - Pelagiusz, Komentarze do Listu św. Pawła do Tytusa, ŹMT 28, Kraków 2003, 9-106.

${ }^{12}$ Por. J. Żelazny, Wstęp, w: Ambrozjaster, Komentarz do Listu św. Pawła do Rzymian, ŹMT 19, Kraków 2000, 5-16.

${ }^{13}$ Por. K. Tyburowski, Unus Adam peccavit in omnibus / in Adam omnes peccaverunt - la solidarietà del genere umano con il peccato di Adamo nel pensiero esegetico dell'Ambrosiaster, w: Ecclesiae Premisliensi Serviens. Księga Jubileuszowa dedykowana Księdzu Infułatowi doktorowi Stanisławowi Zygarowiczowi, Przemyśl 2001, 551-568; tenże, Gli elementi della natura umana secondo l'Ambrosiaster, RSa 8 (2001) 101-115; tenże, I diritti del diavolo sull'umanità peccatrice nella teologia dell'Ambrosiaster, „Studia Catholica Podoliae” 2 (2003) 489-501; tenże, Śmierć jako konsekwencja grzechu Adama wedlug myśli Ambrozjastra, SSan 12 (2005) 62-70; tenże, Przedmiot grzechu Adama w myśli Ambrozjastra na tle współczesnego mu Status Quaestionis, SSan 10 (2003) 239-251.

${ }^{14}$ Por. M.-P. Bussières, Introduction, w: Ambrosiaster, , Contre les païens” (Question sur l'Ancien et le Nouveau Testament 114) et ,Sur le destin” (Question sur l'Ancien et le Nouveau Testament 115), SCh 512, Paris 2007, 29-109.

${ }^{15}$ Por. S. Lunn-Radcklife, Ambrosiaster's Political Theology, Oxford 2007.

${ }^{16}$ Por. A. Baron, Spór o Pawła, spór o człowieka czy spór o Boga? Refleksie na marginesie kontrowersji pelagiańskiej, w: Pelagiusz, Komentarz do listu św. Pawła do Rzymian, ŹMT 15, Kraków 1999, 52-53.
} 
1. Elementy ludzkiej natury. Dla zrozumienia miejsca człowieka w świecie stworzonym należy przywołać trzy opinie Ambrozjastra. W Quaestio II nasz autor pisze:

„Bóg chcąc zniszczyć przedsięwzięcie diabła nie siłą, lecz rozumnymi zasadami, stworzył materię [...] a z niej świat" ${ }^{\prime 17}$.

Stanula stwierdza, że - według Ambrozjastra - Bóg stwarza świat widzialny po upadku diabła, jednak zanim w postawie buntu zjednoczyły się z nim inne anioły. Stwórca wobec uzurpacji nie podejmuje brutalnego rozwiązania, ale biorąc pod uwagę zdolność poznania i wolną wolę swego dzieła pragnie przekonać je o niegodziwości i grzeszności obranej drogi, co uwłaczało samemu buntownikowi ${ }^{18}$.

Drugi tekst pochodzi z Komentarza do Listu św. Pawła do Rzymian:

„Bóg, aby usunąc błąd i okazać się Bogiem wszystkich, zechciał, aby zostało okazane, że może On uczynić i uczyni to, co jest niemożliwe dla świata, ażeby - po potępieniu tych, którzy zadufani w rozumowanie świata wzgardzili Bogiem - ci którzy w to uwierzą, od tamtych oddzieleni, zostali oddani pod panowanie Boga i zbawieni" ${ }^{\prime 19}$.

Staniek odnosząc się do tego fragmentu stwierdza, że wiara ma stanowić reakcję na grzech sprzeniewierzenia się Stwórcy ${ }^{20}$. Podtrzymuje ona zasadę pedagogii, wyjaśnienia błędu i nakłaniania do nawrócenia.

Trzeci tekst został zaczerpnięty z Komentarza do Listu św. Pawła do Kolosan:

„W Chrystusie jest wszelka mądrość i wiedza, ponieważ nie czytają w ewangeliach o astrologii ani u Apostoła o geometrii, ani u proroka o arytmetyce czy muzyce, które [to dziedziny] z tego powodu są przez nas pogardzane, że nie dotyczą zbawienia, lecz raczej wprowadzają w błąd i odciagają od Boga, tak że dopóki przykładają się do nich przez roztrząsania rozumowe, nie prowadzą do zbawienia własnej duszy"21.

${ }^{17}$ Ambrosiaster, Quaestiones Veteris et Novi Testamenti 2, 3, CSEL 50, 18: „deus, ut praesumptionem non potestate, sed ratione destrueret, materiam conddit [...] ex qua faceret mundum", tłum. własne.

${ }^{18}$ Por. Stanula, Aniołowie oraz ich upadek, s. 23.

${ }^{19}$ Ambrosiaster, Commentarius in Epistulam ad Romanos IV 22, 3, CSEL 81/1, 149: „,deus, ut errorem auferret et deum se omnium demonstraret, hoc se posse et fecisse praedicari voulit, quod mundo inpossibile est, ut qui hoc crederent damnatis his, qui ratione mundi inflati deum neglexerunt, discreti salvarentur dei dominio mancipati”, tłum. J. Sulowski: Ambrozjaster, Komentarz do listu św. Pawła do Rzymian, ŹMT 19, 73.

${ }^{20}$ Por. Staniek, Usprawiedliwiajacy charakter chrześcijańskiej wiary, s. 43.

${ }^{21}$ Ambrosiaster, Commentarius in Epistulam ad Colosenses II 1, 3, CSEL 81/3, 179: ,,in Christo omnem esse sapientiam et scientiam, quia non legunt in evangelliis astrologiam, non in apostolo geometricam, non in profeta aritmeticam nec musicam, quae idicirco despecta sunt a nostris, quia ad 
Ambrozjaster wskazuje, że świat wiary prowadzi do pełnego spotkania z Chrystusem, chociaż wymaga to przyjęcia prawdy w formie pozbawionej naukowego opisu świata, jednak nie wyklucza pełnego zrozumienia, ponieważ jego źródłem jest Syn Boga. W konsekwencji Bóg pomimo wydarzenia grzechu podtrzymuje zasadność dzieła stworzenia, czyni z niego przestrzeń do realizacji procesu poznawczego oraz wolnej woli.

Do interpretacji zagadnienia ludzkiej natury u Ambrozjastra istnieją dwa podejścia, prezentowane przez Stanulę i Tyburowskiego. Pierwszy wnioskuje, że według naszego autora ludzka natura składa się z dwóch elementów, duszy i ciała. Dusza łączy człowieka ze światem duchowym. Niemniej, mimo jej pozacielesnego pochodzenia, nie może istnieć poza ciałem, ożywia je i wypełnia. W tym procesie przekazywania życia istotną rolę odgrywała krew. W ramach hierarchii poszczególne elementy różnią się jakościowo. Dzięki duszy człowiek posiada zdolność uczenia się i wolną wolę. Zdobywanie wiedzy dokonuje się przez proces poznawania rzeczywistości oraz przyswajanie informacji otrzymanych od innych. W wolnej woli można wskazać dwa aspekty: wolna wola stwarza możliwość rozwoju bez zmiany natury oraz postępowania wbrew naturze ${ }^{22}$. Drugi element to ciało składające się z czterech pierwiastków: ognia, wody, ziemi i powietrza. Stanowi ono element wspólny właściwy dla wszystkich zwierząt. Ciało człowieka było wyróżnione już od początku, ponieważ nie zostało wyprowadzone z elementów stworzonych wcześniej, lecz uczynione przez Boga jako mieszkanie dla duszy nieśmiertelnejej.

Natomiast według Tyburowskiego Ambrozjaster wyróżnia w człowieku cztery elementy: duch (animus), dusza (anima), ciało (caro) oraz ciało - opozycja duszy (corpus). Tyburowski zwraca uwagę, że poszczególne elementy mają inne znaczenie u św. Pawła, a inne u Ambrozjastra. Nieśmiertelny duch dla Apostoła posiada zdolność poznania oraz wolną wolę. Dlatego stanowi ośrodek podejmowania decyzji, źródło osądu postępowania, uzasadnia przyjęcie bądź odrzucenie prawdy o istnieniu Boga, odkrywa zbawienny plan działania Boga, realizuje posłuszeństwo wobec prawa Bożego. Jest najgłębszą przestrzenią życia człowieka. Pozostaje ośrodkiem natury przez dostęp do prawa. Duch stanowi miejsce zamieszkania dla umysłu oraz tej części wolnej woli, która w momencie podejmowanie decyzji o niegodziwym postępowaniu wyraża sprzeciw ${ }^{24}$.

Dusza w rozumieniu Pawłowym przysługuje tylko człowiekowi i stanowi podstawę fizycznego życia. Nasz autor podąża drogą wyznaczoną przez innych komentatorów i próbuje sprecyzować jej definicję. Odróżnia duszę od

salutem non pertinent, sed magis mittunt in errorem et avocant a deo, ut dum his student ratiocinationum disputationibus, curam animae suae non agant", thum. własne.

${ }^{22}$ Por. Stanula, Nauka Ambrozjastra o stanie pierwotnym człowieka, s. 40-49.

${ }^{23}$ Por. tamże, s. 35-36.

${ }^{24}$ Por. Tyburowski, Gli elementi della natura umana secondo l'Ambrosiaster, s. 103-104. 
ducha, z którym była złączona w sposób harmonijny przed grzechem pierworodnym. Mimo, że podlega duchowi w sferze doskonałości, to jej przysługuje decydująca rola w kształtowaniu indywidualności osoby. Jako pochodząca wprost od Boga formuje ciało, moderując i zapewniając jego jedność. Jest tą częścią natury, która bierze udział w decyzji o grzechu. Chociaż należy do sfery duchowej nieśmiertelność dziedziczy na podstawie decyzji Boga, który wyzwala ją - podobnie jak ciało - od zepsucia ${ }^{25}$.

W refleksji nad ciałem Ambrozjaster przekazuje bardzo wiernie poglądy Apostoła. Caro jest tą częścią ludzkiej natury, która decyduje o tożsamości natury. Kształt został mu nadany w stworzeniu. Jest fundamentem jedności natury (substancją). Z ciała Adama powstaje Ewa i dlatego w relacji małżeńskiej mogą stać się jednym ciałem, w sensie jedności oraz fundamentu przekazywania życia. Ostatecznym argumentem potwierdzającym znaczenie ciała jest wcielenie Syna Bożego. Ciało podlega jednak ambiwalencji, pomimo swojej godności może stać się uczestnikiem grzechu. Staje się on faktem, gdy negatywne zachowania zostają przyjęte za osobiste i obowiązujące ${ }^{26}$.

Przeciwstawienie ciała (corpus) duszy jest raczej poglądem filozoficznym niż biblijnym. Jest ono przedstawiane jako bierna część natury, która doświadcza działania z zewnątrz i przyjmuje (gromadzi) konsekwencje grzesznych decyzji człowieka, w tym także śmierć. Ambrozjaster w ocenie wartości ciała (corpus) pozostaje wierny rozumieniu biblijnemu. Potwierdza jego przynależność do hierarchii świata oraz zdolność do przyjęcia kary. Może to mieć skutki pozytywne - przyjęcie Bożego działania, oraz negatywne - obecność śmierci ${ }^{27}$.

Stanula i Tyburowski wskazują, iż według koncepcji antropologicznej Ambrozjastra istnieją w człowieku dwie sfery: duchowa i materialna. Ich interpretacje nauki naszego autora świadczą o trudności zbudowania statycznej antropologii, wręcz przeciwnie, należy założyć jej dynamiczność. Przede wszystkim dlatego, że komentator postrzega przynajmniej cztery modele powstałe w oparciu o stworzenie, historię człowieka po grzechu pierworodnym, osobę Chrystusa oraz przyjęcie chrztu. Dla Ambrozjastra wszystkie te etapy mają wymiar historii powszechnej, ale stają się także udziałem każdego człowieka. W konsekwencji podstawowym problemem staje się pytanie o warunki przyjęcia w osobie całości historii zbawienia. Stąd wydarzenie Chrystusa jest szczytem antropologii: „Nie byłby zaś prawdziwy, jeśli nie składał się z duszy i ciała"28. Konstrukcja natury ludzkiej umożliwia wcielenie. Antropologia Ambrozjastra jest zorientowana na opis człowieka ochrzczonego wraz ze wskazaniem czynników umożliwiających akt wiary.

${ }^{25}$ Por. tamże, s. 106-109.

${ }^{26}$ Por. tamże, s. 110-112.

${ }^{27}$ Por. tamże, s. 112-115.

${ }^{28}$ Ambrosiaster, Commentarius in Epistulam ad Romanos I 3, 2, CSEL 81/1, 15: ,verus [homo] non erit, nisi sit ex carne et anima”, ŹMT 19, 29. 
Warto dodać jeszcze wyznacznik pneumatologiczny antropologii, szczególnie istotny w momencie śmierci. Brak ciała nie pozbawia poczucia wartości, ponieważ cenniejsze będzie posiadanie Ducha Świętego ${ }^{29}$. Relacja człowieka z Duchem Świętym dokonuje się przez ducha:

„Jeśliby zatem życie [albo poznanie] stało się złe, duch nie będzie nienaruszony, ponieważ opuszcza on człowieka poddanego grzechom. Skoro zatem dusza i ciało nie zgadzają się z Bogiem, [choćby nawet nieświadomie], stają się $\mathrm{Mu}$ obce i duch, niejako tracąc je, nie będzie nienaruszony. Po to bowiem jest dany człowiekowi, aby pozostał w nim [i był jakby jego głowa]. Nie będzie zatem nienaruszony, ponieważ traci członki. [Dokonuje się to wtedy], gdy człowiek oddala się od niego, czyniąc to, czego nienawidzi Duch Święty"30.

Tekst jest niejednoznaczny. Wskazuje bowiem na istnienie ducha jako trzeciego elementu natury. Chociaż pierwotnie jest on bliższy duszy (potwierdzenie jej pochodzenia od Boga), to pod wpływem obecności Ducha Swiętego integruje ciało i duszę, czyniąc z nich części struktury zorganizowanej w nowy sposób, w której jest on głową. Struktura ta jest krucha, narażona na zniszczenie przez niewłaściwą decyzję woli albo błędne poznanie. Decydującą rolę w integracji ludzkiej natury odgrywa Trzecia Osoba Trójcy. Zostaje to wyrażone $\mathrm{w}$ formule bycia na obraz i podobieństwo Boga ${ }^{31}$.

2. Racjonalność poznania. Pneumatologiczne ukierunkowanie natury ludzkiej ma stały charakter. Pierwszorzędna rola w zintegrowaniu duszy i ciała przysługuje woli i poznaniu. W swym podejściu do zagadnienia poznania Ambrozajster przyjmuje ujęcie pedagogiczne. Analizuje powody niewłaściwego poznania, ambiwalentny charakter racjonalności oraz warunki i zakres jej wykorzystania.

Drzewo życia, do którego Adam i Ewa mieli dostęp, podtrzymywało ich życie cielesne. Natomiast zakazane drzewo poznania dobra i zła niosło w sobie tajemnicę, być może - jak przypuszcza komentator - przez jakiś związek z Bogiem, jednak autor nie wyjaśnia, na czym on miał polegać. Pierwsi ludzie, lekceważąc przykazanie Boga, pozbawili się szansy na realizację pełni wolności, osiagnięcie wiecznego życia. Jednak kara zadekretowana przez Boga nie pozbawiła pewnego aspektu wolności tych, którzy jako sprawiedliwi mieli

${ }^{29}$ Por. tenże, Commentarius in Epistulam II ad Corinthios V 2, 2, CSEL 81/2, 229.

${ }^{30}$ Tenże, Commentarius in Epistulam I ad Thesalonicenses V 23, 2, CSEL 81/3, 233-234: „si autem mala vita [vel cogitatio] intercedat, non erit integer spiritus, quia deserit hominem peccatis obnoxium. Dum enim dissentit a deo anima et corpus, [quamvis sine sensu sit,] alieni ab illo efficiuntur et velut perdens eos non erit integer spiritus, ad hoc enim datur homini, ut maneat in eo [et sit quasi caput eius]. Integer ergo non erit, quia perdit membra, dum recedit ab eo homo agens, quae odit sanctus spiritus", tłum. własne.

${ }^{31}$ Por. A. Baron, Mariusz Wiktoryn - człowiek i jego dzieło. Wprowadzenie do dzieł egzegetycznych, w: Mariusz Wiktoryn, Dzieła egzegetyczne, ŹMT 13, Kraków 1999, 49-50. 
oczekiwać na nią w Szeolu ${ }^{32}$. Człowiek nie wykorzystał również szansy poznania istnienia Boga w oparciu o stworzenie:

„[...] skoro stworzenie na własne oczy nie jest w stanie dostrzec potęgi Boga i Jego majestatu, to przymioty te stają się dostępne dla umysłu w oparciu o budowę świata" ${ }^{33}$.

Nasz autor uściśla, że tylko przy pomocy poznania można uznać w objawiającym się bóstwie Boga ${ }^{34}$. Otaczający człowieka świat w swej obecnej formie jest na tyle wyraźny, że pozwala mu odkryć potęgę majestatu Boga, co prowadzi do uznania Jego panowania. Przywrócenie właściwej hierarchii porządkuje stworzenie, wewnętrzną strukturę człowieka oraz relacje społeczne. Grzech polegał na zafałszowaniu prawdy o istnieniu Boga i przekazaniu Jego prerogatyw fałszywym bożkom.

Poznawanie świata przez człowieka może prowadzić go do dwojakiego rodzaju postaw: wraz ze wzrostem wiedzy albo zbliża się on do Boga, albo utwierdza się w przekonaniu o niezależności i powtarza grzech diabła, ogłaszając siebie panem świata:

„Siebie bowiem uważają za mądrych, ponieważ są w stanie - jak sądzą - śledzić teorie fizyczne, badając bieg gwiazd oraz właściwości elementów pomijając ich Pana" 35 .

Objawienie się Boga w świecie przyrody zyskało swe dopełnienie w poznaniu ludzkim. Dzięki niemu jaśniejsza stała się prawda, że stworzony świat był ukierunkowany na Boga, albowiem ostatecznie to umysł pobożny (mens devota) odkrywa sens dzieła stworzenia, warunkując właściwy kult. Poznanie w najbardziej wysublimowanej formie ma charakter religijny. W konsekwencji Ambrozjaster stwierdza, że poznanie i badanie świata tylko wtedy ma sens, gdy jest dokonywane przez człowieka wierzącego:

„Uczonymi zowie tych, którzy wykształceni w sprawach doczesnych zwani są mądrymi w świecie. Chodzi o takich, którzy albo wypatrują gwiazdy, albo zajmują się miarami i liczbami, albo też poświęcają się gramatyce, albo sztuce oratorskiej lub muzyce. Wskazuje, że to wszystko na nic się nie zda, ani też nie są to prawdziwi mędrcy, o ile nie uwierzą w Chrystusa" "36.

\footnotetext{
${ }^{32}$ Por. Ambrosiaster, Commentarius in Epistulam ad Romanos V 12, 3, CSEL 81/1, 163. 165 (redakcja $\gamma$ ).

${ }^{33}$ Tamże I 20, 1, CSEL 81/1, 41: ,cum per se potentia et maiestas dei creaturae oculis aspici non possit, opere mundanae fabricae intellecta videntur", ŹMT 19, 38.

${ }^{34}$ Por. tenże, Quaestiones Veteris et Novi Testamenti 71, 1, CSEL 50, 122-123.

${ }^{35}$ Tenże, Commentarius in Epistulam ad Romanos I 22, 1, CSEL 81/1, 43: „sapientes enim se arbitrantur, quia rationem fysicam investigasse se putant, perscrutantes cursus siderum et quantitates elementorum, deum autem horum spernentes", ŹMT 19, 39.

${ }^{36}$ Tamże I 14, 2, CSEL 81, 33: „sapientes autem illos dixit, qui mundanis rationibus eruditi sapientes vocantur in saeculo, dum aut siderum speculatores sunt aut mensuris aut numeris aut arti
} 
Autor nie potępia biegłości w poznaniu świata, jednak zdobyte informacje okazują się bezwartościowe w porównaniu z przyjęciem prawdy o Chrystusie. Wprawdzie Baalam (por. Lb 23, 1 - 24, 25) oraz trzej magowie (por. Mt 2, 1-12) odwołują się do obserwowania gwiazd, ale do poznania Boga doprowadziło ich pojawienie się niezrozumiałego zjawiska, burzącego ich dotychczasowe rozumienie rzeczywistości ${ }^{37}$. Intelekt stanowi warunek odkrywania i analizowania nowych wydarzeń moderowanych przez Boga:

„Przez intelekt pewne czyny można było dostrzec jako dzieła boskie w Synu, nie było to dostępne oczom cielesnym. [...] W podobny sposób było widziane przez Jakuba dlatego otrzymał imię Izrael, to znaczy człowiek widzący Boga"38.

Możliwość dostrzeżenia obecności Boga w stworzonym świecie nie przekracza naturalnych zdolności człowieka i nie zależy od uprzedniej wiary bądź jej braku. Ambrozjaster nie tylko dopuszcza zdolności poznawcze jako przypisane naturze, ale potwierdza, że są istotne w ukazaniu właściwego obrazu świata. Terminologia stosowana przez naszego autora pozwala na sformułowanie pewnego rozróżnienia: mens oraz ratio opisują poznanie ambiwalentne w swych skutkach. Wspomniana możliwość jest istotna ze względu na założenia egzegezy rabinistycznej, którą posługuje się komentator ${ }^{39}$. Intellectus ma zawsze konotację pozytywną i wiąże się z uznaniem obecności Boga.

Istnieją dwie równoprawne drogi uznania istnienia Boga. Pierwsza, do której mają dostęp Żydzi, polega na obserwowaniu nadzwyczajnych Jego interwencji. Druga, praktykowana przez pogan, polega na rozumowym poznaniu świata materialnego ${ }^{40}$. Brak właściwego zaangażowania poznawczego szkodzi, czego przykładem jest recepcja niektórych kodeksów. Przekładający manipulując treścią pozbawiają ją istotnej prostoty i jasności, zaniedbując sens doprowadzają do napięć i niezgody ${ }^{41}$. Opieszałość poznawcza zamyka dostęp do wielu prawd ukrytych pod zewnętrznymi zjawiskami.

Nasz autor wskazuje, że istotny jest także przedmiot poznania oraz wybór metody:

„Albowiem słowa ludzkiej mądrości nie dostrzegają tego sensu, ani nie jest [on] rozumiany dzięki studiowaniu literatury, lecz jest dostrzegany dzięki rozumieniu poprzez wiarę [...], gdyż więcej poznaje się z prawa natury niż z biegu gwiazd i obliczania [położenia] gwiazdozbiorów, które są wskazywane na

grammaticae student aut oratoriae vel musicae. his omnibus ostendit nihil haec prodesse nec vere sapientes esse, nisi credant in Christum", ŹMT 19, 35.

${ }^{37}$ Por. tenże, Quaestiones Veteris et Novi Testamenti 63, CSEL 50, 111-112.

${ }^{38}$ Tenże, Commentarius in Epistulam ad Colosenses I 15, 3, CSEL 81/3, 171: ,intellectu certe operum divinorum viderunt filium, non carnalibus oculis [...] eodem genere visus est et a Iacob, unde nomen accepit Istrahel, id est homo videns deum", tłum. własne.

${ }^{39}$ Por. Baron, Eacińskie komentarze do listu do Tytusa, s. 50.

${ }^{40}$ Por. Ambrosiaster, Commentarius in Epistulam I ad Corinthios I 24, CSEL 81/2, 17.

${ }^{41}$ Por. tenże, Commentarius in Epistulam ad Romanos V 14, 4e-5, CSEL 81/1, 177. 
niebie. Zatem wierzący widzą, że to, w co wierzą, jest zgodne nie z ludzkimi słowami, lecz z własną naturą"42.

Poznanie związane jest ze znalezieniem sposobu adekwatnego opisu rzeczywistości. Jest to raczej poszukiwanie bliźniaczego istnienia niż teorii. W tym procesie może okazać się pomocny świat stworzony, który pozwala wypracować właściwą metodologię i hierarchię twierdzeń. Nie wystarcza to jednak do zrozumienia wiary, która posiada sobie właściwą wewnętrzną strukturę. Poznanie wypływające z wiary domaga się nowych definicji, przystosowuje do wyrażania nowych treści. W konsekwencji metoda oraz zasady analogii umożliwiają wypracowywanie modeli oddających prawdy wiary: odnośnie do teraźniejszości (Kościół odwzorowany w ludzkim ciele ${ }^{43}$ ) oraz przyszłości (obietnica zmartwychwstania):

„[Paweł] podaje przykłady, aby nie było wątpliwości, że istnieje przyszłe zmartwychwstanie umarłych, żeby nikt, po przyjęciu nauki, nie wątpił" ${ }^{44}$.

Nowe dane poznawcze, dostępne dzięki prawdom wiary, istotnie wspomagają możliwość rozumowej analizy rzeczywistości, tym samym dając właściwe narzędzie do rozstrzygania o wartości twierdzeń.

Ilekroć zostały zakwestionowane ograniczenia umysłu, tylekroć proces poznawczy podążał w złym kierunku. Paradoksalnie, przyjęcie tych ograniczeń prowadziło do odkrycia nowej rzeczywistości (Boga). Wypracowana w oparciu o świat stworzony metodologia oraz zasada analogii pozwalają rozwijać refleksję nad prawdami wiary.

3. Zakres wolnej woli. Poznanie jest czynnikiem determinującym działanie, nadrzędnym w stosunku do wolnej woli:

„[szatan] bowiem rozpalił umysły przewrotnych, żeby ich powstrzymać za pomocą biczowań i więzów, aby nie głosili słowa Bożego" ${ }^{45}$.

Dla odrzucenia wiary w Chrystusa konieczna jest biegłość intelektualna, następnie może ona być wykorzystana do utrudnienia dzieła przekazu prawdy. Takie racjonalne planowanie, choć negatywne w swych skutkach, wymaga

${ }^{42}$ Tenże, Commentarius in Epistulam I ad Corinthios II 13, 2, CSEL 81/2, 29: „verba enim humanae sapientiae hunc sensum non vident, neque litteraturae studiis adprehenditur, sed per fidem ratione concipiuntur [...] naturali enim magis lege quam cursu siderum et calculis signorum, quae in firmamento denotantur, addiscitur. Denique credentes non humanis verbis, sed naturae suae vident congruere quod credunt", thum. własne.

${ }^{43}$ Por. tamże XII 38, 1-2, CSEL 81/2, 143.

${ }^{44}$ Tamże XV 42, CSEL 81/2, 180: ,exempla dat, ut non sit dubium resurrectionem futuram mortuorum, ut accepta ratione nemo ambigat", thum. własne.

${ }^{45}$ Tenże, Commentarius in Epistulam I ad Thesalonicenses II 18, 2, CSEL 81/3, 220: „[satanas] accendebat enim perfidorum mentes, ut eos verberibus ac vinculis detinerent, ne loquerentur verbum dei”, thum. własne. 
zaangażowania poznawczego, konstrukcji teorii. W celu przybliżenia znaczenia wolnej woli zostaną omówione następujące zagadnienia: jej rola, obecność pożądliwości, możliwości rozwoju woli.

Ambrozjster wskazuje, że decyzje wolnej woli mają wpływ na osobę, jednak nie zmieniają jej natury:

„Kiedy bowiem do natury dołącza się zła wola, wówczas natura zasługuje na gniew, to jest, ma być poddana karze nie ze względu na niezmienną substancję, lecz złą wolę. To bowiem uznaje się za element natury, za czym ona postępuje" ${ }^{\prime 4}$.

Problem wolnej woli otwiera pytanie o wartość zmienności wywołanej decyzjami. Dla rozstrzygnięcia tej kwestii Ambrozjaster wprowadza rozróżnienie na substancję i naturę. Pierwsza stanowi czynnik nienaruszalny i niezmienny, w którym umocowana jest wola. Natura w zakresie pojęciowym zbliżona jest do osoby i stanowi całość postępowania zrealizowanego w oparciu o wolne wybory. Możliwość podejmowania decyzji jest niezmienną własnością wolnej woli. Jakość postępowania decyduje o wartości wolnej woli zmieniając, być może, jej strukturę.

Wolna wola podobnie jak poznanie pozwala zwiększać zakres panowania nad rzeczywistością. Może dokonywać się to w sposób negatywny - bliźni posiada przedmiot mego pożądania, albo pozytywny - otrzymuje nowy zakres wolności, wcześniej niedostępnej. Pożądanie stanowi istotny element ludzkich relacji. Zostało ono zadekretowane po grzechu pierwszych rodziców, a dysproporcja relacji kobieta - mężczyzna będzie rzutować destrukcyjne na szersze odniesienia $\mathrm{w}$ ramach wspólnoty ${ }^{47}$. Dlatego w ramach dekalogu zostaje wydany zakaz prawny:

„Otóż Prawo zabrania pożądliwości, o której nie sądzono, że jest grzechem dlatego, że sprawia przyjemność. Pożądać bowiem czegoś u bliźniego wydawało się sprawą zwyczajną. Dopiero Prawo ujawniło, że jest to grzechem. Albowiem ludziom żyjącym według zasad światowych nic nie wydaje się bardziej bezkarnym i przyjemnym, aniżeli rozkosz"${ }^{\prime 48}$.

Prawo nakazuje zweryfikować decyzje podjęte wyłącznie w oparciu o zasadę przyjemności. Chęć posiadania nie stanowi jedynego czynnika określającego

${ }^{46}$ Tenże, Commentarius in Epistulam ad Efesios II 3, 3, CSEL 81/3, 71-126, 80: „naturae enim cum mala voluntas subponitur, fit natura irae, id est quae ultioni subicienda sit inmutata non substantia, sed mala voluntate. Hoc enim deputatur naturae quod sequitur", tłum. własne.

${ }^{47}$ Por. Historia dogmatów, red. B. Sesboüé, t. 2: Człowiek i jego zbawienie, tłum. P. Rak, Kraków 2001, 153.

${ }^{48}$ Ambrosiaster, Commentarius in Epistulam ad Romanos VII 7, 3, CSEL 81/1, 223: „lex itaque concupiscentiam prohibet, quae propterea quod oblectamento est, non putabatur esse peccatum. simplex enim videbatur causa concupiscere aliquid proximi; hoc lex prodidit esse peccatum. saecularibus enim namque hominibus nihil tam inultum et placidum videtur quam voluptas", ŹMT 19, 101. 
wartość woli. Związana z nią siła nie stanowi usprawiedliwienia dla bezprawnego posiadania. Dopiero rozumność i wewnętrznie uporządkowane działanie bazujące na zasadzie sprawiedliwości może we właściwy sposób ukształtować zakres wolności ${ }^{49}$. Warto zaznaczyć, że wstrzemięźliwość niesie wzmocnienie wewnętrznej siły, która pozwala przeciwstawić się złym skłonnościom ${ }^{50}$. Działanie pozbawione zasad rodzi niebezpieczeństwo pozbawienia możliwości wykonywania rozeznanego dobra ${ }^{51}$.

Ukierunkowanie woli rodzi zależność i podporządkowanie - szatanowi bądź $\mathrm{Bogu}^{52}$. Oczywiście z punku widzenia chrześcijan uleganie złu jest popadaniem $\mathrm{w}$ grzech, ale nie zmienia to faktu, że człowiek z osobistym zaangażowaniem poszukuje nowych sposobów realizacji zależności ${ }^{53}$.

Oprócz wolności wewnętrznej pojawia się wymiar zewnętrzny. Pochodzi on wyłącznie od Chrystusa ${ }^{54}$ :

„Wcześniej nie było takiego przypadku, abyśmy byli uwolnieni od śmierci dzięki komuś. Chrystus nas odkupił, nie bóstwa"55.

Pokonanie śmierci przez Chrystusa daje ludziom podwójną wolność: od szatana i od ograniczenia życia. Dzięki temu otwiera się nieskończona możliwość realizacji wolności. Nie zmienia się ona pod względem własności, ale zwiększa zakres dostępu. Wraz z nową rzeczywistością pojawiają się nowe zasady:

„Tymczasem przytoczył nie więcej niż dziesięć rzeczy, które wskazał jako owoce Ducha, aby się wydawało, że w nich zawarł wszystko zgodnie z tablicami Bożego testamentu, na których zostało przekazanych nie więcej niż dziesięć słów przykazań” ${ }^{56}$.

Wykorzystanie nowych możliwości rodzi dotąd niespotykane owoce, które są znakiem wewnętrznego zharmonizowania osoby. Ostatecznie znakiem pełnej wolności jest stopień integracji osoby, przejawiający się w przyjęciu zasad Ducha Świętego.

Wolna wola stanowi istotny element funkcjonowania osoby. Ulega poszerzeniu w podwójny sposób: przez powiększenie stanu posiadania albo

\footnotetext{
${ }^{49}$ Por. tamże V 7, 3a-4a, CSEL 81/1, 159 (redakcja $\gamma$ ).

${ }^{50}$ Por. tamże I 32, 1-2, CSEL 81/1, 59.

${ }^{51}$ Por. tamże VII 18, 4, CSEL 81/1, 239.

${ }^{52}$ Por. Baron, Spór o Pawła, spór o człowieka czy spór o Boga?, s. 81.

${ }^{53}$ Por. Ambrosiaster, Commentarius in Epistulam ad Romanos I 24, 1, CSEL 81/3, 47.

${ }^{54}$ Por. tamże I 17, 3, CSEL 81/1, 39.

${ }^{55}$ Tenże, Commentarius in Epistulam I ad Timotheum VI 19, 3, CSEL 81/3, 293: ,nullum exemplum videtur, quod aliquem a morte liberarunt. Christus nos redemi, non divitiae", thum. własne.

${ }^{56}$ Tenże, Commentarius in Epistulam ad Galatas V 24, 2, CSEL 81/3, 61: ,interea non amplius quam decem res posuit, quas fructus spiritus significavit (significant), ut in his omnia conplexus videatur secundum tabulas testamenti dei, in quibus non amplius quam decem verba mandatorum tradita sunt", thum. własne.
} 
wzmocnienie wewnętrznej siły. Pierwsza droga może wiązać się z pożądliwością, co przynosi negatywne skutki. Druga ma charakter pozytywny. W perspektywie chrystologicznej zostaje poszerzony zakres wolności, lecz aby go dobrze wykorzystać należy wypełnić prawo Ducha Świętego.

Ambrozjaster należy do rzymskiej szkoły egzegetycznej, gdzie podstawową zasadą było wyjaśnianie ,słowa przez słowo”. W pierwszym rzędzie zasada ta dotyczyła chrystologii, następnie hermeneutyki. W odniesieniu do pisarzy komentujących teksty św. Pawła trudno mówić o ich oryginalności, gdyż wyjaśniali oni Pismo Święte w duchu środowiska, w którym działali, dlatego ważne jest wydobycie podobieństw między poszczególnymi autorami ${ }^{57}$. Ambrozjastra i Mariusza Wiktoryna łączy pneumatologiczne ukierunkowanie natury oraz podkreślanie wartości ciała; z Pelagiuszem - model wolnej woli: nie jako absolutnej niezależności, ale jako odniesienia do Boga; Augustyn od naszego autora zaczerpnął dwie koncepcje: pożądania oraz przekazywania grzechu pierworodnego przez ciało ${ }^{58}$.

Pisma przypisywane Ambrozjastrowi mają charakter egzegetyczny i ukierunkowane są na wyjaśnienie poszczególnych wersetów Pisma Swiętego, nie zaś na systematyczny wykład. W powyższym artykule wskazano główne zręby antropologii. Zostały one ukazane w trzech punktach: elementy ludzkiej natury, racjonalność poznania, zakres wolnej woli. Decydującą rolę w integracji elementów ludzkiej natury - duszy i ciała - odgrywa Duch Święty. Obraz i podobieństwo do Boga wyrażają się w zdolności przyjęcia Trzeciej Osoby Trójcy i aktywnym rozwoju pod Jej kierunkiem. Wspomniany proces jest trójetapowy. Pierwszym etapem jest zbudowanie wiarygodnego opisu rzeczywistości stworzonej. Właściwie opracowany model definiuje świat jako drogę do uznania istnienia jednego Boga. Wypracowana metoda oraz system weryfikacji pozwala przejść do kolejnego etapu, którym jest przyjęcie prawd wiary. Tworzenie w ich ramach modeli teologicznych daje pogłębione rozumienie Trójcy Świętej. W konsekwencji wymusza przebudowanie antropologii, która staje się adekwatna do stopnia wartości prawdy objawionej. Ostatni etap to autorozumienie osoby ludzkiej, która ukazuje się jako dialogiczna (wartość budowana w oparciu o odniesienie do Trójcy Świętej) i eschatologiczna (oczekiwanie na utrwalenie się dialogu w niezmiennej rzeczywistości).

Rola środowiska eklezjalnego oraz kulturowego stanowi istotny klucz dla rekonstrukcji poglądów komentatorów. Środowisko to miejsce kreowania dialogu, aktywnego życia i relacji, więc z konieczności jego zakres musi być ograniczony. Rodzi się pytanie, czy obok antiocheńskiej i aleksandryjskiej

\footnotetext{
${ }^{57}$ Por. Staniek, Usprawiedliwiajacy charakter chrześcijańskiej wiary, s. 183.

${ }^{58}$ Por. Historia dogmatów, t. 2, s. 179.
} 
można mówić też o metodzie rzymskiej szkoły egzegetycznej (Mariusz Wiktoryn, Ambrozjaster, Pelagiusz, Augustyn).

\section{COGNITION AND FREE WILL - THE TWO MAIN CATEGORIES OF AMBROSIASTER'S ANTHROPOLOGY}

\section{(Summary)}

Ambrosiaster belongs to the Roman school of exegesis. He deserves the attention because of the relations between him and Marius Victorinus, his predecessor, as well as Pelagius and Augustine, his successors. The purpose of the article was to present Ambrosiaster's anthropology on the basis of his writings. The conclusions have been presented in three parts: the elements of human nature, the rationality of knowledge and the scope of free will.

The first part shows the process in which the elements of nature are integrated. The spirit plays the decisive role synchronizing both the body and the soul. This dynamic and ongoing process is inspired by the presence of the Holy Spirit. The second part reveals two conditions for gaining knowledge: accepting the limitations of the mind and expanding and developing the principle of analogy. The last part presents two ways the free will is practised: by increasing how much one owns, which may be associated with lust, or by strengthening one's inner strength. The role of the cultural and the ecclesial environment constitutes important information for the reconstruction of the views of Ambrosiaster. This raises the question whether - alongside Antioch and Alexandria - one could also talk about the Roman school of exegesis (Marius Victorinus, Ambrosiaster, Pelagius).

Key words: anthropology, body, cognition, exegesis, free will, lust, spirit, soul.

Słowa kluczowe: antropologia, ciało, duch, dusza, egzegeza, poznanie, pożądanie, wolna wola. 
